\title{
The optimal Relevance of American Dream Metaphor Translation
}

\author{
Dwi Aji Prajoko \\ Universitas Sebelas Maret \\ Surakarta, Indonesia \\ dwiaji.prajoko@gmail.com \\ Djatmika \\ Universitas Sebelas Maret \\ Surakarta, Indonesia \\ djatmika@staff.uns.ac.if
}

\author{
M.R. Nababan \\ Universitas Sebelas Maret \\ Surakarta, Indonesia \\ amataradja@yahoo.com \\ Tri Wiratno \\ Universitas Sebelas Maret \\ Surakarta, Indonesia \\ tri_wiratno@staff.uns.ac.id
}

\begin{abstract}
In successful communication, the listener believes that the utterance speaker communicates has optimal relevance, namely the utterance that needs minimal processing and gives maximal contextual effects (Sperber \& Wilson, 2005: 360). It is getting more interesting when Gutt (in Venuti, 2013: p. 71) applies the relevance theory on translation. Accordingly, the purpose of this research was to describe the optimal relevance of the translation of American dream metaphor in Fitzgerald's novel entitled The Great Gatsby (TGG). To collect the data three technigues are used, namely document analysis, interview, and focus group discussion (FGD). The informants were the experts of American dream metaphor and of translation. The results showed that TGG translated into Indonesian by Nataresmi (TGG-N) obtained $209(87.08 \%)$ for minimal processing and 137 $\mathbf{5 7 . 0 8 \%}$ ) for maximal contextual effects; TGG translated into Indonesian by Verawaty (TGG-V) reached $220(91.66 \%)$ for minimal processing and $165(68.75 \%)$ for maximal contextual effects. On a scale of 1 to 3 , the optimal relevance of TGG-N was 2,56 while TGG-V 2.73. This indicates that in terms of processing, TGG-V is better than TGG-N; in terms of contextual effects, TGG-V is also better than TGG-N; and, terefore, in terms of optimal relevance, TGG-V is better than TGG-N. However, both of the translation versions obtain optimal relevance.
\end{abstract}

Keywords--translation; optimal; relevance; conceptual; metaphor

\section{INTRODUCTION}

Mao's utterance "revolution is not a dinner party" is proportional, true, and clear; however, the question of its relevance makes the listener aware that the utterance is actually a metaphor (Steinhart \& Kittay, 1994); the Chinese leader says "not graceful and pleasant" with "not a dinner party." This emphasizes two things. Firstly, metaphor is essentially a way of expressing something with something else. Secondly, Spelberg \& Wilson (1986) gain legitimacy by adopting only one maxim, namely the maxim of relevance, out of four Gricean maxims; they give birth to the Relevance theory, therefore. In the following turn, Gutt (in Venuti, 2000, p. 376-7) seeing translation as "interpretive use across language boundaries" applies the optimal relevance to the field of translation.
The presence of conceptual metaphor theory brings a new perspective in the world of metaphor translation, which is not only finding linguistic correspondence between two different languages, but also seeking the linkage of two conceptual systems of two different cultures. Schäffner (2004, p. 1258) even earlier states, "... translatability is no longer a question of the expression of individual metaphors, as identified by ST, but it becomes associated with the level of conceptual systems in the source and target culture."

For some reasons, TGG becomes the analyzed document to get the data. Firstly, TGG is a literary work with the tremendous testimony of metaphorical expressions. Secondly, TGG has a great theme, namely the American dream desired by the main character Jay Gatsby (Callahan, 2006, p. 97) and the other characters. Thirdly, TGG is so popular that it is highly adapted into some operas, plays, films, et cetera. Fourthly, TGG is a quality novel; therefore, it becomes the American standard of literary work and ranks two of the hundred best American novels of the twentieth century. Fifthly, TGG attracts the translation industries including Indonesian publishers publishing two Indonesian translation versions in 2010.

\section{Methodology}

\section{A. Data forms, Sources, and Vollection}

The data were the source domain of metaphorical expressions in the form of words, phrases, or clauses about American dream in the novel TGG written by F. Scott Fitzgerald; they were validated by an expert; the data about the optimal relevance of translation were in the form of numbers expressesing the points of achievement; they were obtained from the focus group discussion (FGD) involving the researcher and three other translation experts. Accordingly, the data were collected by analyzing the documents and by asking and discussing with the expert informants. 


\section{B. Data analysis Techniques}

The data analysis technique of this research was etnographic covering domain analysis, taxonomic analysis, componential analysis, and cultural theme analysis (Spradley 2007, p. 199). This was circular in nature, meaning that even though it had been up to the stage of cultural theme analysis, it could be back to the stage of componential analysis, the stage of taxonomic analysis, or even the stage of domain analysis.

The domain analysis was to distinguish data and not data. In this research, the existence of American dreams and of metaphorical expressions were the differentiators. The taxonomic analysis was to analyze all data based on predefined domains. In this case, all of the American dream metaphor translations were seen from the domains of the optimal relevance; the domains are the processing and contextual effects. The componetial analysis was to analyze the relationship between the various components in the various domains that had been established, for example, analyzing the similarities and contrasts between the processing of TGG-N and that of TGG-V. The cultural theme analysis was to conclude the relationship patterns between the domains and how they were linked to the culture as a whole.

\section{Optimal Relevance Assesment Instruments}

The optimal relevance occured due to the old and the new information connection (Sperber \& Wilson, 1995, p. 119). In the case of translation, the linkage was between the translation and the contextual information provided by the cognitive environment. It was a psychological construct representing one's perception of the world in a particular place and time including logical, encyclopedic and lexical information; logical information contained various inference rules causing the readers to reason; encyclopaedic information covered information about objects, properties, and events helping the readers to make inference; lexical information enabled the readers to interpret natural sentences and utterances (Akman \& Surav, 1995, p. 25).

The relation between the old and the new information made the translation become "clear and natural" (Venuti, 2000, pp. 334-335) and, therefore, needed minimal processing only. In this research, the translation could be classified as clear and natural for some reasons. First, the translation used a familiar metaphorical expression; it did not matter if the metaphor was the original or the adaption. Second, the translation used a new metaphorical expression but it was based on a familiar metaphorical concept giving a room for the readers to make inference. Third, the translation made the original message explicit but used common words, phrases, or clauses. Such a translation got the highest score (three). Next, the translation that made the old and new information incompletely related had middle score (two) because they required little additional processing to digest them. Finally, the translation that made the old and new translation almost completely unrelated had the lowest score (one) because it required much addtional processing time.

The old-new information connection also affected the maximization of contextual effects, namely by producing new axioms, to strengthen the existing ones, or to fight against or even to abolish them (Akman \& Surav, 1995, p. 25). However, translation had something to do with the interpretive similarity; hence, contextual effect was related to the explicatures and implicatures. The translation sharing more explicatures and implicatures with the original text got the interpretive similarity. Explicature was part of the assumptions presented analytically by the utterance or text, while the implicature was part of the contextual and contextual implications of the text or speech; text and texts with original translations to approach an interpretive resemblance (Zhonggang 2006, p. 46). Table I shows the instrument used to asses the optimal relevance.

TABLE I. OPTIMAL RELEVANCE ASSESSMNT INSTRUMENT

\begin{tabular}{|c|c|c|c|}
\hline & $\begin{array}{l}\text { Translation } \\
\text { category }\end{array}$ & Score & Qualitative parameter \\
\hline \multirow[t]{3}{*}{ Processing } & Minimal & 3 & $\begin{array}{l}\text { The translation is clear and } \\
\text { natural }\end{array}$ \\
\hline & Little additional & 2 & $\begin{array}{l}\text { The translation is less clear } \\
\text { and natural }\end{array}$ \\
\hline & Much additional & 1 & $\begin{array}{l}\text { The translation is the least } \\
\text { clear and natural }\end{array}$ \\
\hline \multirow[t]{3}{*}{$\begin{array}{l}\text { Contextual } \\
\text { effects }\end{array}$} & Maximal & 3 & $\begin{array}{l}\text { The translation shares } \\
\text { explicatures and } \\
\text { implicatures of the original. }\end{array}$ \\
\hline & Less maximal & 2 & $\begin{array}{l}\text { The translation shares less } \\
\text { explicatures and } \\
\text { implicatures of te original. }\end{array}$ \\
\hline & The least maximal & 1 & $\begin{array}{l}\text { The translation shares the } \\
\text { least explicatures and } \\
\text { implicatures of the original. }\end{array}$ \\
\hline
\end{tabular}

\section{FINDING AND DISCUSSION}

\section{A. Processing}

\section{1) Minimal processing}

The word advantages replaces "wealth" in Table II, so it is the important part of linguistic metaphor/metaphorical expression based on the conceptual metaphor/metaphorical concept WEALTH IS HAVING MORE; it is American dream metaphor because its domain is wealth (kekayaan).

TABle II. Minimal Processing

\begin{tabular}{|l|l|c|}
\hline Source language & Target language & $\begin{array}{l}\text { Processing } \\
\text { score }\end{array}$ \\
\hline $\begin{array}{l}\text { 001/TGG/3 } \\
\text { 'Whenever you feel } \\
\text { like criticizing any } \\
\text { one,' he told me, 'just } \\
\text { remember that all the } \\
\text { people in this world } \\
\text { haven't had the } \\
\text { advantages that }\end{array}$ & $\begin{array}{l}\text { 001/TGG-N/1 "Setiap kau merasa } \\
\text { ingin menilai seseorang," ia berkata } \\
\text { padaku, "ingatlah bahwa tidak semua } \\
\text { orang di dunia ini memiliki } \\
\text { keberuntungan sepertimu." }\end{array}$ & 3 \\
\cline { 2 - 3 } you've had.' & $\begin{array}{l}\text { 001/TGG-V/7 "Setiap kali kamu } \\
\text { ingin mengkritik seseorang," katanya, } \\
\text { "ingatlah bahwa semua orang di } \\
\text { dunia ini tidak memiliki kelebihan } \\
\text { seperti yang kamu miliki." }\end{array}$ & \\
\hline
\end{tabular}

The word "keberuntungan" (advantage) in TGG-N can be processed minimally; it gets the top score, namely 3 points. The translation is clear and natural. Even though having the similar metaphorical expressions, "keberuntungan" is not the literal translation of advantages. The word "keberuntungan" is the manifestation of metaphorical concept WEALTH IS HAVING MORE that is also known in the target language. 
For example, "iri hati melihat keberuntungan orang lain," "keluarga beruntung," et cetera. Thus, the translation readable and acceptable.

Similarly, the word "kelebihan" in TGG-V gets 3 points too because of its clarity and naturalness. The words "kelebihan" and advantages are different metaphorical exressions, but both are based on the same metaphorical concept WEALTH IS HAVING MORE. The expression like "orang berlebih,"

$209(87.08 \%)$ out of 240 metaphorical expression translations in TGG-N got minimal processing. $220(91.66 \%)$ translations in TGG-V also acquired minimal processing. Thus, majority of both translation versions had minimal processing.

\section{2) Little additional processing}

The long words promising to unfold the shining secrets that only Midas and Morgan and Maecenas knew in Table III are the source domain of American dream metaphor for two reasons; firstly, they are based on the metaphorical concept GOOD BOOKS ARE SUCCESS SECRET REVEALERS; secondly, they bring an optimistic view on the books; in this research optimism is subdomain of American dream conducive situation.

\section{TABle III. Little Additional Processing}

\begin{tabular}{|c|c|c|}
\hline Source language & Target language & $\begin{array}{c}\text { Processing } \\
\text { score }\end{array}$ \\
\hline \multirow[t]{2}{*}{$\begin{array}{l}015 / \text { TGG/6 ... they } \\
\text { stood on my shelf in } \\
\text { red and gold like new } \\
\text { money from the mint, } \\
\text { promising to unfold } \\
\text { the shining secrets } \\
\text { that only Midas and } \\
\text { Morgan and } \\
\text { Maecenas knew. }\end{array}$} & $\begin{array}{l}\text { 015/TGG-N/5-6 Semua buku itu } \\
\text { disusun di rak buku dengan } \\
\text { sampulnya yang merah dan } \\
\text { keemasan seperti uang yang } \\
\text { baru keluar dari percetakan, } \\
\text { menyimpan janji dalam lipatan } \\
\text { rahasia yang kemilau yang hanya } \\
\text { diketahui oleh Midas dan Morgan } \\
\text { dan Maecenas }\end{array}$ & 2 \\
\hline & $\begin{array}{l}\text { 015/TGG-V/12... semuanya berdiri } \\
\text { di rak dengan warna merah dan } \\
\text { emas seperti uang baru dari } \\
\text { percetakan, sebuah janji untuk } \\
\text { membuka rahasia-rahasia } \\
\text { berkilau yang hanya diketahui } \\
\text { oleh Midas, Morgan, dan } \\
\text { Maecenas }\end{array}$ & 2 \\
\hline
\end{tabular}

That everything Midas touches turns to gold must be wellknown for westerners whose culture is rooted to Greek myth; the saga of Morgan as a successful businessman must become American collective memories; even Maecenas - the wealthy person and the patron of art-must be familiar for American and European readers. Nevertheless, the pure borrowing of Midas and Morgan and Maecenas makes Indonesian readers need extra time to process these unfamiliar figures. Both versions, TGG-N and TGG-V, adopt the pure borrowing. Consequently, each of them get 2 points.

There were 19 translations in TGG-N which got little additional processing and 16 translations in TGG-V which gained little additional processing. Thus, minority of both translation versions took little additional processing.

\section{3) Much additional processing}

The words like an ecstatic patron of recurrent light in Table IV are the source domain of American dream metaphor. The reasons are that they are based on the metaphorical concept A HAPPY PERSON IS A LIGHT PROTECTOR and that they talk about the most important thing in American dream: happiness.

\section{TABle IV. Muchadditional Processing}

\begin{tabular}{|l|l|c|}
\hline Source language & Target language & $\begin{array}{c}\text { Processing } \\
\text { score }\end{array}$ \\
\hline $\begin{array}{l}\text { 138/TGG/96 When } \\
\text { he realized what I } \\
\text { was talking about, } \\
\text { that there were } \\
\text { twinkle-bells of } \\
\text { sunshine in the room, } \\
\text { he smiled like a } \\
\text { weather man, like an } \\
\text { ecstatic patron of }\end{array}$ & $\begin{array}{l}\text { 138/TGG-N/127 Saat ia menyadari } \\
\text { apa yang kubicarakan pada saat itulah } \\
\text { berkilat-kilat cahaya kemilau di } \\
\text { ruangan, ia tersenyum seperti } \\
\text { pecurrent light. } \\
\text { penjaga cahaya yang bergembira. }\end{array}$ & $\begin{array}{l}\text { 138/TGG-V/139 Ketika Gatsby } \\
\text { menyadari apa yang sedang aku } \\
\text { "bicarakan" bahwa ada "lonceng } \\
\text { berdenting ceria" di dalam ruangan } \\
\text { ini, dia tersenyum seperti peramal } \\
\text { cuaca, seperti seorang pelindung } \\
\text { cahaya yang sangat gembira. }\end{array}$ \\
\hline
\end{tabular}

The metaphorical concept HAPPY PERSONS ARE LIGHT PROTECTOR is not found in the target language. Therefore, the result of the literal translation seriously slows down the processing. The points are the lowest. Both translation versions do the literal translation, that is why, each gets only one point.

There are 12 translations in TGG-N getting much additional processing. The sum is the lowest too. TGG-V also has 4 translations with much additional processing. Luckily, the sum of this kind of translation is also the lowest.

\section{B. Contextual effect}

1) Maximal contextual effect

The metaporical concept HAPPINESS IS ORIGINALITY is the basis of metaphorical expression whose source domain is the prase an original settler (see Table V). Besides the metaphorical concept reason, the prase becomes the datum due to discussing the most crucial domain of American dream: happiness.

TABle V. Maximal Contextual EFFects

\begin{tabular}{|l|l|c|}
\hline Source language & Target language & $\begin{array}{c}\text { Contextual } \\
\text { effect } \\
\text { score }\end{array}$ \\
\hline $\begin{array}{l}\text { 010/TGG/6 And as I } \\
\text { walked on I was } \\
\text { lonely no longer. I } \\
\text { was a guide, a } \\
\text { pathfinder, an } \\
\text { original settler. }\end{array}$ & $\begin{array}{l}\text { 010/TGG-N/5 Dan ketika aku } \\
\text { meneruskan perjalanannya, aku } \\
\text { merasa tidak lagi kesepian. Kini aku } \\
\text { seorang pendamping, penunjuk jalan, } \\
\text { seorang penghuni asli. }\end{array}$ & 3 \\
\cline { 2 - 3 } & $\begin{array}{l}\text { 010/TGG-V/11-2 Dan saat aku } \\
\text { melanjutkan perjalanan, aku tidak } \\
\text { lagi sendirian. Aku pemandu, } \\
\text { penunjuk jalan, penduduk asli. }\end{array}$ & \\
\hline
\end{tabular}

The unhappiness of a new comer is loneliness. Nick feels such feeling. His unhappiness, therefore, is gone when he has a company a to whom he can do guiding and pathfinding like an original setler. Hence, if the clause "I was lonely no longer" 
implies that he undergoes some feeling trasformation, namely from unhapiness to happiness, the metaphorical phrase an original settler implies (the cause of) happiness itself. TGG-N and TGG-V successively translate the phrase into "penghuni asli" and "penduduk asli." Both are good for retaining the metaphor, therefore, sharing the original implicature, and for their meaning faithfullness.

TGG-N had 137 (57.08\%) maximal contextual effects. Quantitatively speaking, the sum was the first rank. TGG-V got $165(68.75 \%)$ maximal contextual effects. It was also the highest.

\section{2) Less maximal contextual effect}

The metaphorical expression whose source domain is the prase bloomed with (see Table VI) is based on the metaporical concept LIGHT IS FLOWER. Room with full of light is associated with wealth. Accordingly, it is the domain of American dream. The metaphorical concept and the wealth domain are reasonable explanation to include the phrase as the datum.

TABLE VI. LESS MAXIMAL CONTEXTUAL EFFECT

\begin{tabular}{|l|l|c|}
\hline Source language & Target language & $\begin{array}{c}\text { Contextual } \\
\text { effect } \\
\text { score }\end{array}$ \\
\hline $\begin{array}{l}\text { 055/TGG/21 Inside, } \\
\text { the crimson room } \\
\text { bloomed with light. }\end{array}$ & $\begin{array}{l}\text { 055/TGG-N/25 Di dalam, ruangan } \\
\text { berdinding merah tua diterangi } \\
\text { cahaya. }\end{array}$ & 2 \\
\cline { 2 - 3 } & $\begin{array}{l}\text { 055/TGG-V/33 Di dalam, ruangan } \\
\text { merah tua semarak dengan cahaya. }\end{array}$ & 2 \\
\hline
\end{tabular}

If the phrase bloomed with light were translated into ditaburi cahaya, the translation still would retain the metaphorical concept LIGHT IS FLOWER eventhouh the metaphorical expression is different. Unfortunately, TGG-N and TGG-V sucessively translate the prase into diterangi and semarak dengan. Indeed, both the translation versions are faithfull to the meaning because of the correct explicitation. Nevertheless, they miss the implicature of the original that make them get the less maximal contextual effect. The score of both translation versions are two.

TGG-N and TGG-V got almost the same sum in having less maximal contextual effects, namely 58 (24.16\%) for TGG-N and 57 (23.75\%) for TGG-V.

\section{3) The least maximal contextual effect}

The prase one slice in a long white cake of (see Table 3.6) is the source domain of the metaphorical expression which is based on the metaporical concept GOOD BUILDINGS ARE FAVOURABLE FOOD. The metaphorical concept and the fact that it is about wealth, namely apartment house as the domain of American dream, make the phrase become the datum.

TABLE VII. The LEAST MaXimal CONTEXTUAL EFFects

\begin{tabular}{|l|l|c|}
\hline Source language & Target language & $\begin{array}{c}\text { Contextual } \\
\text { effect } \\
\text { score }\end{array}$ \\
\hline $\begin{array}{l}\text { 067/TGG/29 At } \\
\text { 158th Street the cab } \\
\text { stopped at one slice }\end{array}$ & $\begin{array}{l}\text { 067/TGG-N/39 Di Jalan158, taksi } \\
\text { berhenti di depan pintu di antara } \\
\text { deretan blok apartemen bercat }\end{array}$ & 1 \\
\hline
\end{tabular}

\begin{tabular}{|l|l|c|}
\hline in a long white cake & putih. & \\
\cline { 2 - 3 } $\begin{array}{l}\text { of apartment } \\
\text { houses. }\end{array}$ & $\begin{array}{l}\text { 067/TGG-V/48 Di 158 Street taksi } \\
\text { berhenti di salah satu bagian } \\
\text { sepanjang gugusan putih }\end{array}$ & 1 \\
\hline \begin{tabular}{l} 
apartemen. \\
\hline
\end{tabular} & \\
\hline
\end{tabular}

Making explicit the cake metaphor makes TGG-N not share the original implicature. Furthermore, the translation also loses the meaning that the house is comfortable to stay in like the cake is nice food to eat. Unfortunately, TGG-V also does similarly. Because of missing the implicature and the meaning of the original, both translation versions get the lowest point, namely one.

For the least maximal contextual effects, TGG-N got 45 $(18.75 \%)$ while TGG-V 18 (7.5\%). Luckily, the sum of the fatal mistakes were in the lowest of the three divisions.

On a scale of 1 to 3 , the optimal relevance of TGG-N was 2,56 while TGG-V 2.73. Furthermore, TGG-N and TGG-V had some similarities. Both reached the top parts on the minimal processing and the maximal contextual effects, the lower parts on little additional processing and less maximal effects, and the lowest ones on much additional processing and the least maximal effects. In some cases, they also did similar mistakes.

\section{CONCLUSION}

The fact that majority of both the translations get the minimal processing and the maximal contextual effects indicates that the translations strive for optimal equivalence. The final scores even confirm that both reach the optimal relevance even though TGG-V is better than TGG-N in the areas of both processing and contextual effects. Besides, the massive use of metaphor in the translation sthrengthens the idea of conceptual metaphor theory proposed by Lakoff \& Johnson (2003) that metaphor is inevitable in our life.

\section{References}

Akman, V., \& Surav, M. (1995). Contexts, oracles, and relevance. Bilkent, Ankara: Bilkent University.

Callahan, J.F. (2006). Use of American iconography. In H. Bloom (Ed.), Bloom's Guide: F Scott Fitzgerald The Great Gatsby (97-102). New York: Infobase Publishing.

Fitzgerald, F.S. (1925). The great gatsby. Retrieved from http://ebooks. adelaide.edu.au/

Fitzgerald, F.S. (2010). The great gatsby. (S.N. Verawaty, Trans.). Jakarta: Serambi. (Original work published 1925).

Fitzgerald, F.S. (2010). The great gatsby. (U. Nataresmi, Trans.). Surabaya: Selasar. (Original work published 1925).

Gutt, E.A. (2000). Translation as interlingual interpretive use. In L. Venuti (Ed.) The translation studies reader. London and New York: Routledge.

Lakoff, G., \& Johnson, M. (2003). Metaphors we live by. London: The University of Chicago Press. 
Schaffner, C. (2004). Metaphor and translation: Some implications of a cognitive approach. Journal of Pragmatics, 36, 1253-1269.

Sperber, D., \& Wilson, D. (1986). Relevance: communication and cognition. Oxford: Blackwell.

Sperber, D., \& Wilson, D. (2005). Pragmatics. In F. Jackson \& M. Smith (Eds.), The Oxford Handbook of Contemporary Philosophy (353-388). Oxford: Oxford University Press.

Spradley, J. P. (2007). Metode etnografi (2nd ed.). (M.Z. Elizabeth, Trans.). Yogyakarta: Tiara Wacana. (Original work published 1979).

Steinhart, E., \& Kittay, E.F. (1994). Metaphor. In R.E. Asher \& JMY Simpson (Eds.), Encyclopedia of language and linguistics. (pp.2452-6). Oxford: Pergamon.

Venuti, L. (2013). Translation changes everything: theory and practice. New York: Routledge.

Zhonggang, S. (2006). A relevance theory perspective on translating the implicit information in literary texts. Journal of Translation, 2(2), 43-60. 